This item was submitted to Loughborough's Research Repository by the author.

Items in Figshare are protected by copyright, with all rights reserved, unless otherwise indicated.

\title{
Surface temperature of tools during the high-pressure die casting of aluminium
}

PLEASE CITE THE PUBLISHED VERSION

PUBLISHER

(C) IMechE / Professional Engineering Publishing

VERSION

VoR (Version of Record)

LICENCE

CC BY-NC-ND 4.0

\section{REPOSITORY RECORD}

Norwood, Andrew J., Phill M. Dickens, Rupert C. Soar, and Russell A. Harris. 2019. "Surface Temperature of Tools During the High-pressure Die Casting of Aluminium”. figshare. https://hdl.handle.net/2134/4738. 
This item was submitted to Loughborough's Institutional Repository (https://dspace.lboro.ac.uk/) by the author and is made available under the following Creative Commons Licence conditions.

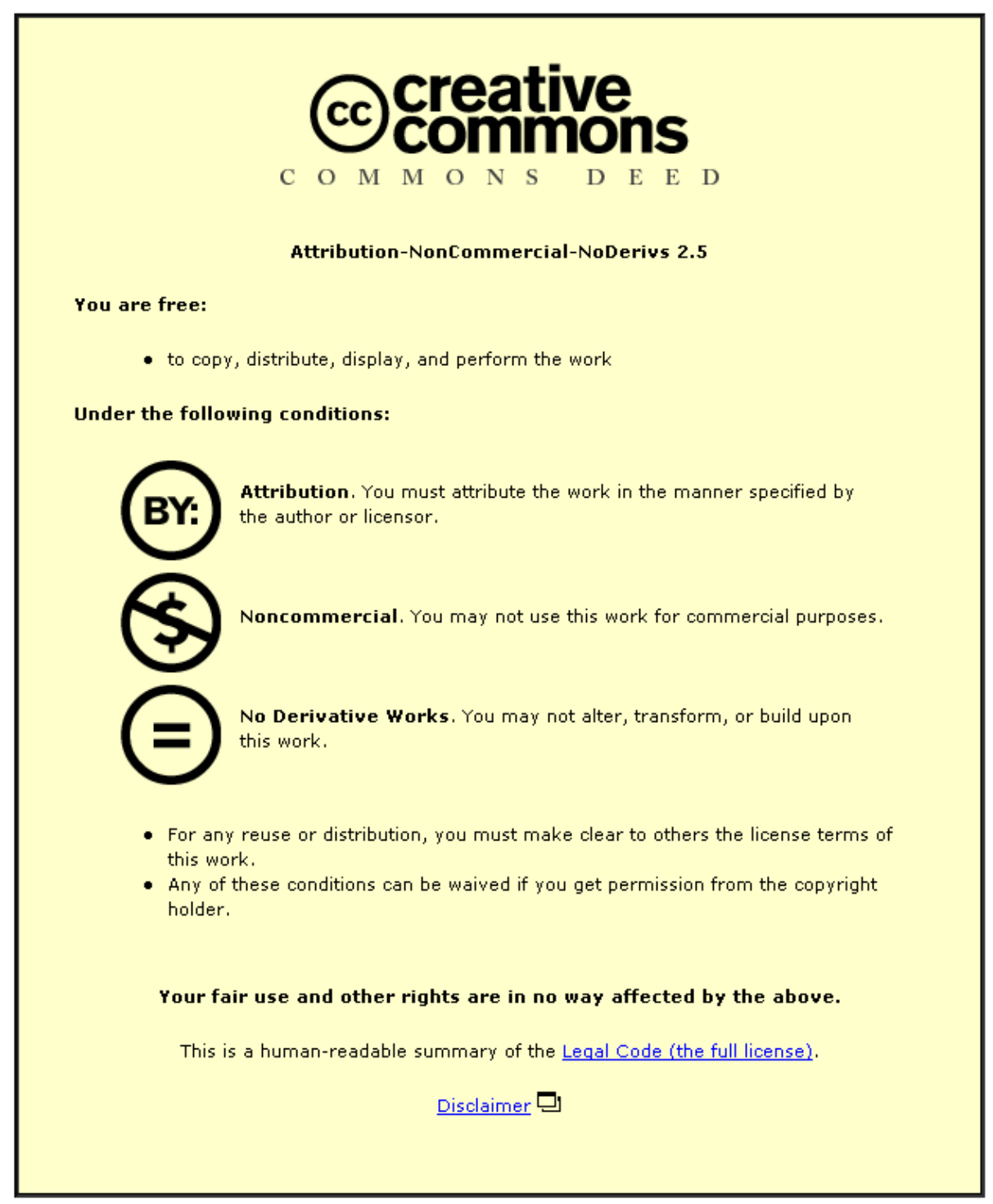

For the full text of this licence, please go to: http://creativecommons.org/licenses/by-nc-nd/2.5/ 


\title{
Surface temperature of tools during the high-pressure die casting of aluminium
}

\author{
A J Norwood, P M Dickens*, R C Soar, and R A Harris \\ Wolfson School of Mechanical and Manufacturing Engineering, Loughborough University, Loughborough, UK \\ The manuscript was received on 22 September 2006 and was accepted after revision for publication on 30 August 2007.
}

DOI: 10.1243/09544054JEM745

\begin{abstract}
The objective of this work was to determine the temperature experienced within a pressure die-casting tool during aluminium part production. It was important to determine the temperature profile of the production process so that an accurate thermal cycle could later be simulated. The research overcame several challenges of this aggressive environment to show that the surface temperature of a die could be obtained from an H13 steel tool running on an aluminium pressure die-casting machine. The results show that the surface of a typical aluminium pressure die-casting tool heats to $400-450{ }^{\circ} \mathrm{C}$ within approximately $1 \mathrm{~s}$ and cools to $150-200{ }^{\circ} \mathrm{C}$ within approximately $20 \mathrm{~s}$.
\end{abstract}

Keywords: surface temperature, tools, high-pressure die casting, aluminium

\section{INTRODUCTION}

In cold-chamber die casting, the molten material is forced into the die via a hydraulic plunger-piston in three controlled phases producing high-quality castings. The process can be used with zinc-, magnesium-, aluminium-, and copper-based alloys.

Phase 1 is termed take up and slowly pushes the aluminium towards the die with minimum turbulence.

Phase 2 is the injection phase (filling of the die cavity). The cold-chamber pressure die-casting process typically casts aluminium alloys which are injected at $700-750{ }^{\circ} \mathrm{C}$ depending on the die geometry. This phase has to be fast enough to prevent chilling while the alloy is filling the die. The speed of this phase is approximately $10 \mathrm{~m} / \mathrm{s}$ and typically takes $0.05-0.1 \mathrm{~s}$; however, speeds can be as high as $100 \mathrm{~m} / \mathrm{s}$ [1]. During this phase, any gases are expelled via machined vents in the die and through the parting line.

Phase 3 is the compaction phase, as the alloy solidifies in the cavity it begins to shrink away from the surface of the die. The force applied to the alloy $\left(50-70 \mathrm{~N} / \mathrm{mm}^{2}\right)$ reduces this effect and reduces the size of inclusions and porosity caused by air, trapped during injection.

*Corresponding author: Wolfson School of Mechanical and Manufacturing Engineering, Loughborough University, Loughborough, Leicestershire LE11 3TU,UK.email: p.dickens@ lboro.ac.uk
The die is usually water cooled and the surface sprayed with water-based die lubricant, causing thermal shock.

The most important properties required of materials for die-casting tools are resistance to thermal fatigue and resistance to softening at elevated temperatures. Resistance to softening is required to withstand the erosive action of molten metal under high injection pressures and speeds. The performance of die-casting dies is related to the casting temperature of the work metal, the thermal gradients within the dies, and the frequency of exposure to a high temperature. During the high-pressure die casting of aluminium the die has to withstand severe operating conditions such as high pressure and rapid temperature fluctuations and, over time, tool failure occurs $[2,3]$. In actual die casting, the dominant tool failure mechanism is thermal fatigue cracking [4]. Initially molten metal contacts the die and causes the surface temperature to increase above that of the interior of the die [5]. The die face starts to expand; however, the cooler underlying layer resists this expansion, creating a temporary compressive stress layer [6, 7]. When the casting is removed, the die surface starts to cool and, as it does, the surface shrinks or contracts. The surface cools more quickly than the interior of the die; this places the subsurface of the die into residual tensile stress, which is made worse by the application of die lubricant [8]. During further cycling, the die surface is subjected to alternating 
compressive and tensile stresses that result in plastic deformation [9]. Continued cycling reduces the yield strength of the tool, causing increased residual tensile stresses to develop and cracks to initiate. This type of cracking is more prevalent in aluminium and brass die casting because of the higher temperatures and resulting thermal shock by the molten metal.

To understand how a tool material behaves when subjected to thermal fatigue it is important to know the process temperature cycle (heating rate, cooling rate, temperature difference, mean temperature, cycle duration, etc.).

Persson $[4,10]$ investigated the thermal fatigue temperature profiles and conditions of brass pressure die casting and developed a test method. The die's surface temperature during casting was measured by four probes in a production die for tube couplings. The probes had a diameter of $16 \mathrm{~mm}$ which housed a small cylindrical test disc behind which $\mathrm{K}$-type thermocouples (with thin wires of diameter $0.13 \mathrm{~mm}$ ) were spot welded to the back of the discs. The thicknesses of the discs were $0.25,0.5,2$, and $5 \mathrm{~mm}$. The temperature of the molten brass was $980^{\circ} \mathrm{C}$ and was used with a cycle time of $30 \mathrm{~s}$ during which the die was closed for $10 \mathrm{~s}$ and opened for $20 \mathrm{~s}$. Water at $20^{\circ} \mathrm{C}$ circulated continually in the die and the surfaces were lubricated. The shot mass of each casting was $1.6 \mathrm{~kg}$ with a peak casting pressure of $164 \mathrm{MPa}$.

During the first few cycles (less than 20) the tool ramped up from room temperature to a steady state of $300^{\circ} \mathrm{C}$. Persson et al. [11] described a typical die surface temperature cycle as follows: 'When the $980^{\circ} \mathrm{C}$ melt makes contact with the tool, the tool material is heated within about $0.35 \mathrm{~s}$ from around $300{ }^{\circ} \mathrm{C}$ to a maximum temperature of around $750{ }^{\circ} \mathrm{C}$ at a surface depth of $0.25 \mathrm{~mm}$ '. 'Until the tool is opened, cooling occurs by heat conduction into the bulk of the tool. Die opening and simultaneous cast ejection give rise to an additional heat loss through irradiation and convection.'

Bounds [12] investigated the thermal behaviour of the zinc pressure die-casting process by measuring the temperature of the die to obtain the operating conditions. J-type mineral-insulated thermocouples were placed through the die block and die surface so that they would be in contact with the casting, and additional thermocouples were positioned $2.5 \mathrm{~mm}$ behind the die surface. The zinc solidus was at $380^{\circ} \mathrm{C}$, the liquidus at $386{ }^{\circ} \mathrm{C}$, and the casting alloy temperature, prior to injection, was $410^{\circ} \mathrm{C}$. The report detailed a problem with the response rate of the thermocouples.

Aluminium pressure die-casting research regarding die temperature is limited. However, Persson's [4] research estimated the aluminium die surface temperature to be $520^{\circ} \mathrm{C}$. Srivastava et al. [6] stated that a typical die surface temperature reaches a maximum of $457^{\circ} \mathrm{C}$ and can be cooled to $107^{\circ} \mathrm{C}$.

Research has shown that on average the external surface temperature of the shot sleeve directly below the pouring hole reached $350^{\circ} \mathrm{C}$ while the internal temperature reached between $480^{\circ} \mathrm{C}$ and $500^{\circ} \mathrm{C}[13]$. The shot sleeve removes a significant amount of heat from the molten aluminium prior to injection. When injected, the aluminium formed a skin on impact with the die and the mass of the die cooled the metal so rapidly that the surface temperature never reached the aluminium pour temperature $[\mathbf{1 4}, \mathbf{1 5}]$. This was confirmed by Oberg et al. [16] who stated: 'Although the die is hot, metal entering the die is cooled quickly, producing layers of rapidly chilled, dense material about 0.015 in $(\gg 0.4 \mathrm{~mm})$ thick in the metal having direct contact with the die cavity surface'; this is termed the skin effect.

\section{EXPERIMENTAL PROCEDURE}

A series of tests was planned to establish the temperature profile of an aluminium pressure die-casting tool surface, under production conditions.

Obtaining a temperature profile was a difficult process because of the high pressures and speed of solidification in the pressure die-casting process. The main problem was locating and securing the thermocouples in position on the surface of the die. They had to be located and secured such that they resisted being pushed back into the bolster owing to the injection pressure; otherwise aluminium would escape from the cavity.

In order to be relevant to normal practice a typical industrial aluminium pressure die-casting tool was required that could be modified to accommodate thermocouples. The tool needed to be manufactured from $\mathrm{H} 13$ tool steel (standard die material) to ensure that the thermal characteristics of the tool were accurate.

A typical production H13 multi-cavity (four) aluminium die-cast tool was chosen. This was a tool for a clutch housing. The tool consisted of five inserts, three on the moving half (Fig. 1(a)) and two on the fixed half; this arrangement made tool modification easier since they could easily be removed from the bolster and, if damaged, replaced. The casting had a shot mass of $250 \mathrm{~g}$ with runner and biscuit and all four components (Fig. 1(b)), and an individual component had a mass of $14 \mathrm{~g}$ (Fig. 2).

The casting alloy used was $\mathrm{Al}-8 \% \mathrm{Si}-3 \% \mathrm{Cu}$ or LM24 (BS 1490 or ASTM B85-03). The alloy is commonly used for pressure die casting because its material properties are well suited to the process. Aluminium is prone to hydrogen absorption when molten, which can cause porous castings; this was 


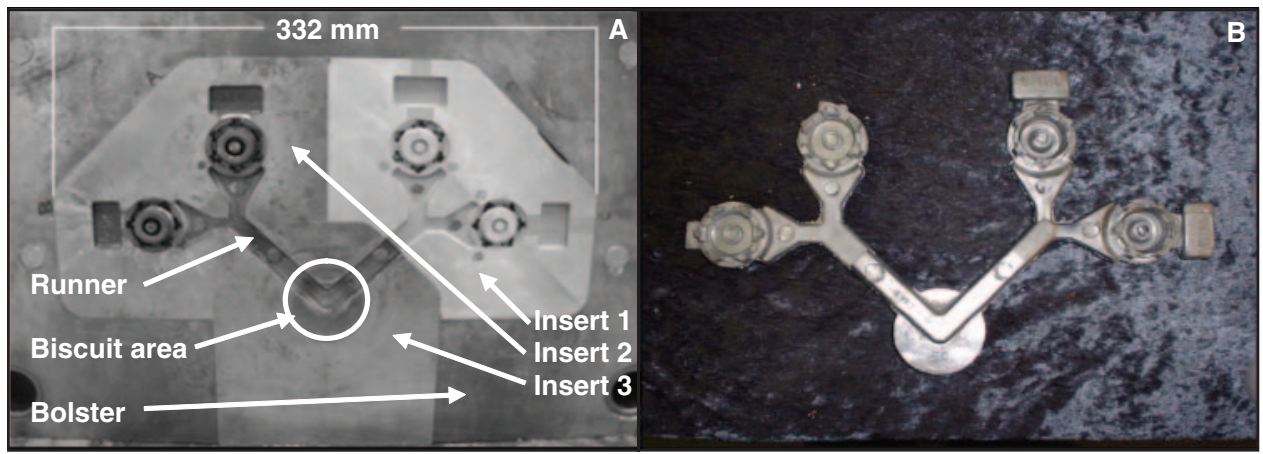

Fig. 1 (a) Moving half of the tool; (b) clutch housing casting

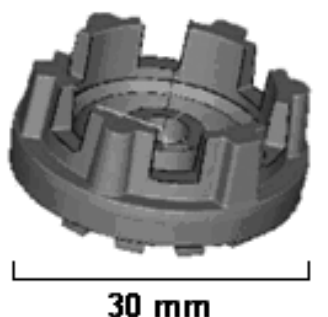

Fig. 2 Computer aided design image of 'Dyson' clutch housing

resolved by modifying the alloy in the furnace by degassing. The aluminium was degassed by bubbling nitrogen through the molten alloy. The alloy also required fluxing (Foseco, Coverall 11); this separated the dross from the molten aluminium so that is rose to the surface, creating a protective layer that hydrogen could not penetrate. The dross was only removed at the beginning of the casting process. A sample of molten aluminium was taken in order to test the gas level using a hydrogen gas analyser; it was found to contain $0.15-0.25 \mathrm{~cm}^{3}$ of gas per $500 \mathrm{~g}$, which was within typical casting limits.

The machine used had to be large enough to accommodate the size of the die and the shot mass. A Frech DAK 125 SDV cold-chamber machine was used. The machine parameters are shown in Table 1 with the casting cycle shown in Fig. 3. For consistency of die cooling, the automated die lubricator on the machine was utilized. The die lubricant (release agent) was Acheson DeltaCast 333 release 3, at a temperature much higher than $20-25^{\circ} \mathrm{C}$; this was sprayed on to the die surface immediately prior to each shot, through six nozzles for $3 \mathrm{~s}$.

As in production, the die was initially heated to approximately $150{ }^{\circ} \mathrm{C}$ with a gas lance and 50 shots run through to heat the die to the operating temperature.

Measuring the surface temperature was difficult and several attempts and test adaptations were conducted. An initial attempt to determine the surface temperature of a die resulted in an aluminium blowout, causing considerable loss of time because the die had to be disassembled cleaned, repaired, and
Table 1 Casting parameters

\begin{tabular}{ll}
\hline Parameter & Value \\
\hline Machine type & Frech DAK 125 SDV \\
Maximum piston velocity (phase 1) & $0.15 \mathrm{~m} / \mathrm{s}$ \\
Maximum piston velocity (phase 2) & $0.8 \mathrm{~m} / \mathrm{s}$ \\
Start of phase 2 & $140 \mathrm{~mm}$ \\
Start of phase 3 & $270 \mathrm{~mm}$ \\
Maximum shot chamber length & $315 \mathrm{~mm}$ \\
Maximum die closing force & $125 \mathrm{t}$ \\
Alloy & $\mathrm{LM} 24$ \\
Pouring temperature & $750^{\circ} \mathrm{C}$ \\
Initial temperature of die & $180^{\circ} \mathrm{C}$ \\
Die coating material & DeltaCast $333 \mathrm{R3}$ \\
Total cycle time & $20-24 \mathrm{~s}$ \\
Piston diameter & $50 \mathrm{~mm}$ \\
In-gate speed & $2.48 \mathrm{~m} / \mathrm{s}$ \\
Shot mass & $250 \mathrm{~g}$ \\
System pressure & $105 \mathrm{bar}$ \\
\hline
\end{tabular}

reassembled. It was obvious from the first attempt that the thermocouples required relocation, resulting in the machining of the bolster and the insert, to secure two calibrated mineral-insulated K-type endground thermocouples of $0.25 \mathrm{~mm}$ diameter by means of a collet. The size of the thermocouples was important because, the smaller the diameter of the wire, the faster is the reaction speed. A compromise had to be made; if the thermocouple is too small, it would be destroyed and, if it is too large, its response rate would be too slow. The thermocouple tips were positioned at the die surface to allow direct contact with the molten aluminium as it entered the die. Temperature-sensitive paints were placed in the biscuit and runner system of the aluminium die cast tool as these areas are typically subjected to the most heat (Fig. 4). However, it was found that, as the aluminium was being forced down the runners, it washed the paints away. The location of the paints was changed to the overflow region of the die, to solve this problem. The thermocouples were connected via a compensating cable to a computer data logger controlled by National Instruments LabVIEW ${ }^{\mathrm{TM}}$ version 5.1.1 software. It enabled several thermocouples to be connected at once. The data could also be loaded into Microsoft Excel. 


\begin{tabular}{|c|c|c|c|c|c|c|c|}
\hline \begin{tabular}{|l|} 
Operator \\
Starting \\
Cycle \\
$1-2$ sec
\end{tabular} & \begin{tabular}{|l} 
Die \\
Close \\
1 sec
\end{tabular} & \begin{tabular}{|l|} 
Ladling \\
$5-8$ \\
sec
\end{tabular} & \begin{tabular}{|l} 
Injection \\
1 sec
\end{tabular} & $\begin{array}{l}\text { Solidification } \\
3 \mathrm{sec}\end{array}$ & $\begin{array}{l}\text { Die } \\
\text { Open } \\
3 \text { sec }\end{array}$ & $\begin{array}{l}\text { Ejection } \\
3 \mathrm{sec}\end{array}$ & \begin{tabular}{|l} 
Release \\
Agent \\
3 Sec
\end{tabular} \\
\hline
\end{tabular}

Fig. 3 Casting machine process cycle

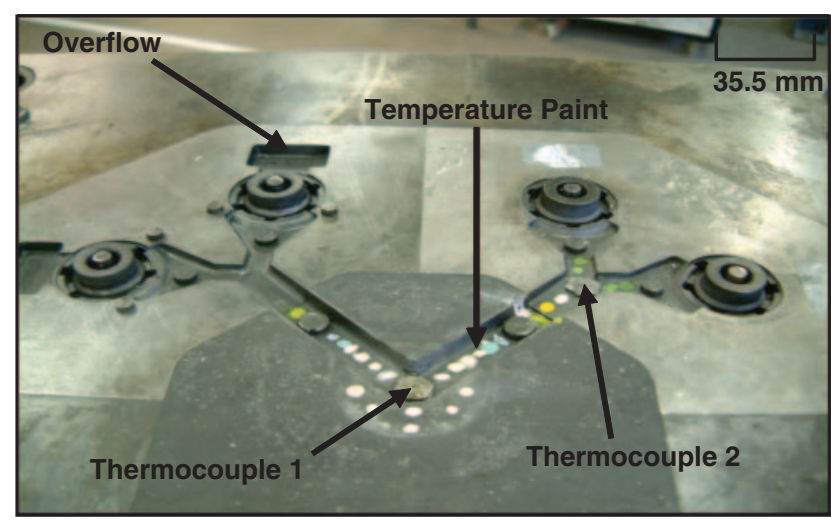

Fig. 4 Location of the thermocouples and temperature paint on the moving half of the tool

\section{RESULTS}

Figure 5 shows the results obtained from the first test. Unfortunately the thermocouple in the runner failed when the die was warmed to $250^{\circ} \mathrm{C}$ as it was directly next to the gas lance. The thermocouple in the hottest area (biscuit) survived and the test continued showing that the surface temperature of the die reached $350{ }^{\circ} \mathrm{C}$ and cooled to between $150^{\circ} \mathrm{C}$ and $200^{\circ} \mathrm{C}$ with a typical cycle time of $20-24 \mathrm{~s}$. However, the paints suggested that the surface temperature was between $399{ }^{\circ} \mathrm{C}$ and $454^{\circ} \mathrm{C}$. It was clear that the reaction time of the thermocouples was too slow because of the large wire diameter and the insulation. Hence, the results obtained were not representative of the surface temperature in an aluminium pressure die-casting cycle because the thermocouples were not able to measure the temperature sufficiently rapidly.

To overcome the problem in the previous experiment, several fibreglass-insulated K-type open-ended thermocouples, with a wire diameter of $0.3 \mathrm{~mm}$, were stuck to the surface of the die. These thermocouples have a faster reaction time since they are open ended. There was, however, a question over their ability to survive the conditions long enough to enable a temperature reading to be obtained.

An additional problem was that the die could not be preheated as before since the thermocouples were fixed to the surface of the die with tape. However, a few shots were run through the die to increase the temperature prior to applying the thermocouples.
The results showed that on occasion the die temperature reached over $450^{\circ} \mathrm{C}$ but was typically between $400^{\circ} \mathrm{C}$ and $450^{\circ} \mathrm{C}$ (Fig. 6). The paints verified this.

Unfortunately the cooling profile could not be obtained using the small thermocouples as they failed upon opening the die. However, the cooling profile could be approximated from Fig. 5. Cooling occurred over a longer period of time (much longer than $20 \mathrm{~s}$ ), allowing the thermocouples to respond. This allowed the aluminium pressure die-casting thermal cycle shown in Fig. 7 to be determined.

\section{DISCUSSION}

Using thermocouples and temperature paints it was possible to obtain the temperature profile of an aluminium pressure die-casting tool.

The results of this work showed that the surface temperature of the die reached between $400{ }^{\circ} \mathrm{C}$ and $450^{\circ} \mathrm{C}$ and cooled to between $150^{\circ} \mathrm{C}$ and $200{ }^{\circ} \mathrm{C}$. Persson's [4] research was on brass pressure die casting and not aluminium. Persson recorded that the surface temperature of the die reached $980^{\circ} \mathrm{C}$ but cooled rapidly to $750^{\circ} \mathrm{C}$ in $0.35 \mathrm{~s}$ and then cooled to approximately $300^{\circ} \mathrm{C}$ over the remainder of the cycle (much longer than $29.65 \mathrm{~s}$ ). Despite the fact that Persson used brass, it was clear that there are similarities between the die temperature profile of a brass die and an aluminium die with the only difference being the higher temperatures (brass has a higher casting temperature than aluminium). Both experience rapid cooling as the molten metal hits the die surface and they have similar cooling profiles over the cycle time. Persson, however, did estimate that the surface of an aluminium die would reach $520^{\circ} \mathrm{C}$. Srivastava [6] also stated that an aluminium pressure die-casting tool surface reached a maximum temperature of $457^{\circ} \mathrm{C}$ and cooled to $107^{\circ} \mathrm{C}$. These suggestions are in keeping with the tool temperature results of this work $\left(450-150^{\circ} \mathrm{C}\right)$.

In addition, the profile shown in Fig. 7 is believed to be correct as research [13] has shown a shot sleeve to reach an internal surface temperature of $480-500{ }^{\circ} \mathrm{C}$ with a significant amount of heat being lost by the molten metal (typically poured at $700^{\circ} \mathrm{C}$ ) prior to injection. In turn, the tool surface temperature was recorded to reach $400-450^{\circ} \mathrm{C}$. Research has shown that, as molten aluminium contacts the surface of the 


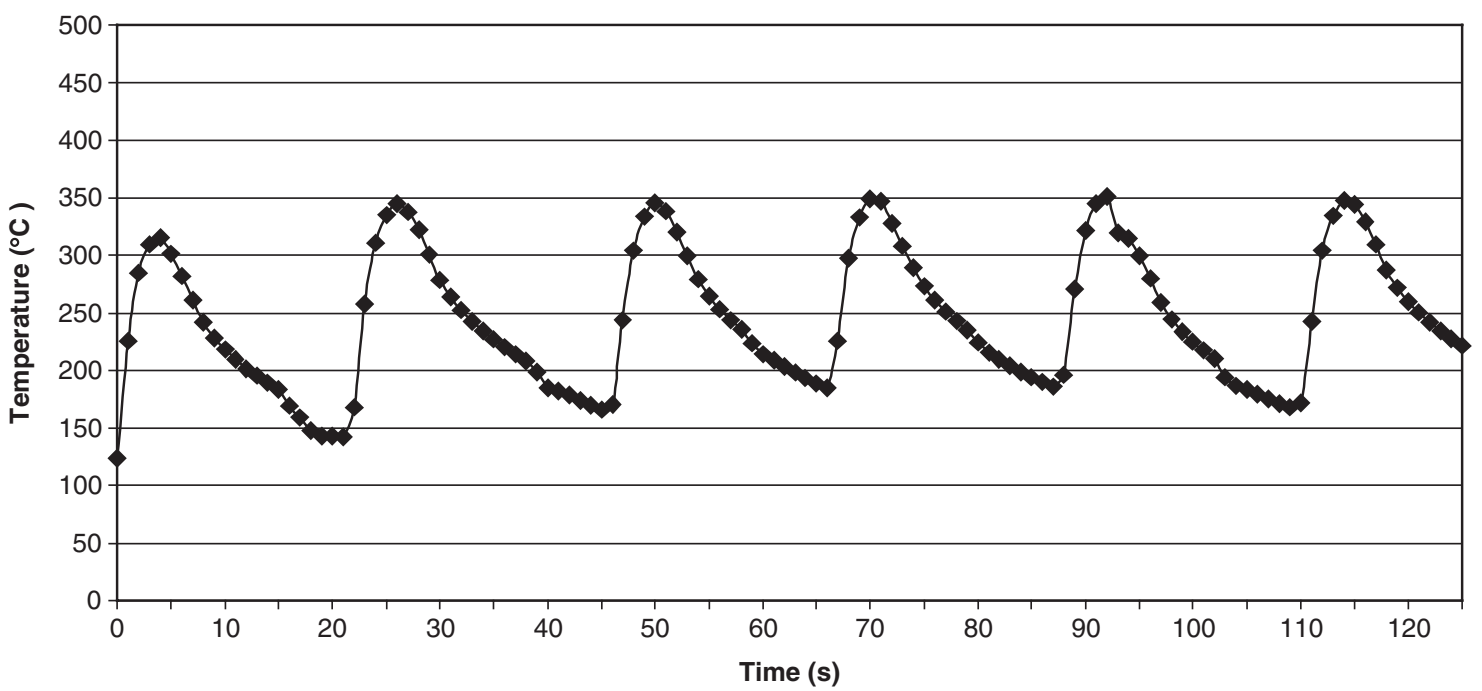

Fig. 5 Graph showing the tool surface temperature during casting (biscuit area)

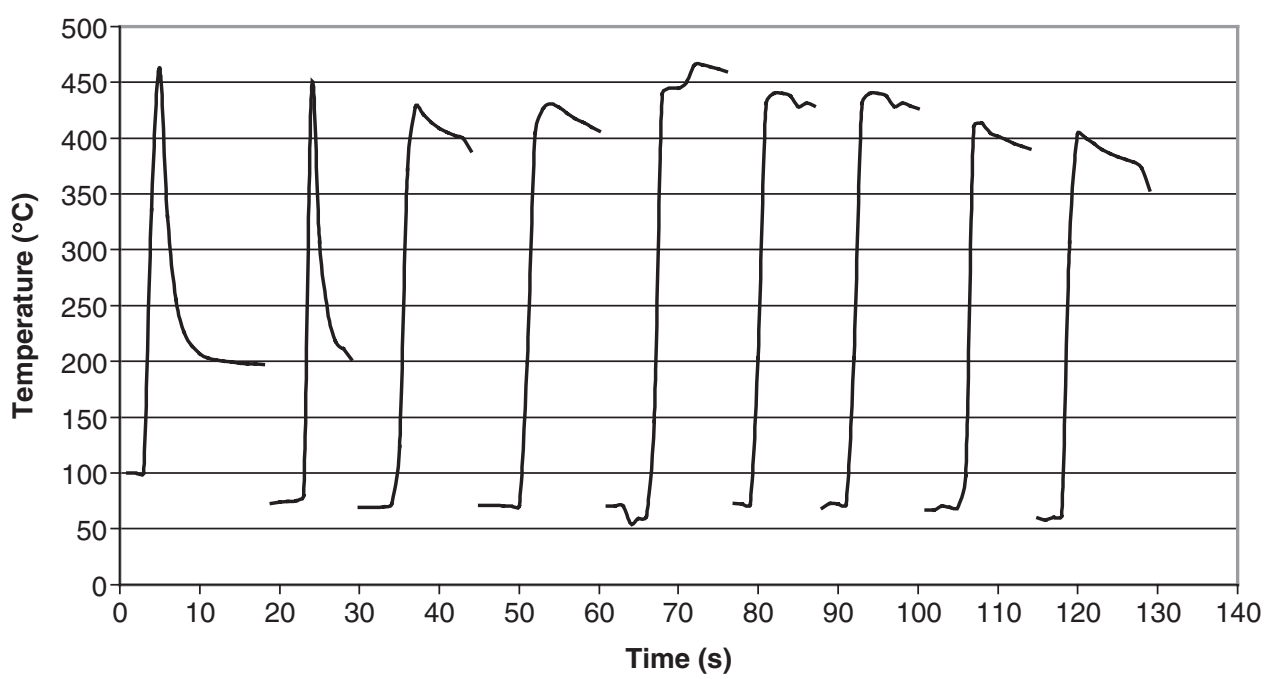

Fig. 6 Tool temperature review

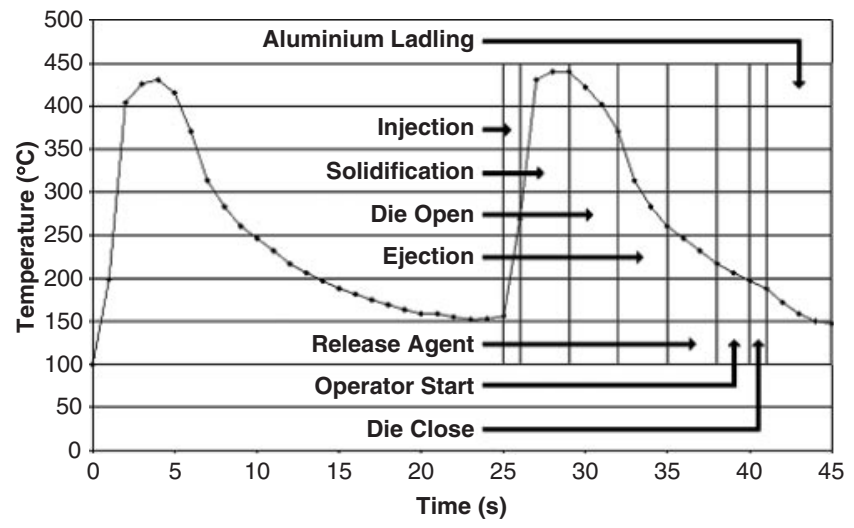

Fig. 7 Aluminium pressure die-casting thermal cycle

die, a thin layer freezes instantaneously and the die never reaches the temperature of the molten material $[14,15]$. The mass of the die draws the heat away rapidly during solidification. Upon die opening, ejection, mould spray, etc., the die surface begins to cool more rapidly, as shown in Fig. 7.

\section{CONCLUSIONS}

This work highlights the difficulty of determining the surface temperature of a tool during aluminium die casting. However, it has clearly shown the temperature at the surface of a typical aluminium pressure die-casting tool and revealed that the surface heats to $400-450^{\circ} \mathrm{C}$ within approximately $1 \mathrm{~s}$ and cools to $150-200^{\circ} \mathrm{C}$ within approximately $20 \mathrm{~s}$.

\section{FUTURE WORK}

Subsequent work will be to use these results in a new fatigue test and then to proceed to evaluate tooling materials for die casting. 


\section{REFERENCES}

1 Chen, Z. W. Formation and progression of die soldering during high pressure die casting. Mater. Sci. Engng A, 2005, 397, 356-369.

2 Gulizia, S., Jahedi, M. Z., Doyle, E. D., and Chen, Z. W. Application of duplex surface treatments for aluminium high pressure die casting tools. Tooling 1999 Conference Proceedings, 1999, pp. 205-210 (Melbourne Institute of Materials Engineering, Melbourne).

3 Sjoström, J. and Bergström, J. Thermal fatigue testing of chromium martensitic hot work tool steel after different austenitising treatments. J. Mater. Process. Technol., 2004, 153-154, 1089-1096.

4 Persson, A. Tool failure in die casting. Doctoral Thesis, Uppsala University, Department of Materials Science, 2003.

5 Schwam, D., Wallace, J. F., and Birceanu, S. Effect of design factors on thermal fatigue cracking of die casting dies. Final Report, Department of Materials Science, Case Western Reserve University, Cleveland, Ohio, Project DE-FC07-00ID138486, US Department of Energy, Washington, DC, October 2004.

6 Srivastava, A., Joshi, V., Shivpuri, R., Bhattacharya, R., and Dixit, S. A multilayer coating architecture to reduce heat checking of die surfaces. Surf. Coatings Technol., 2003, 163-164, 631-636.

7 Srivastava, A., Joshi, V., and Shivpuri, R. Computer modelling and prediction of thermal fatigue cracking in die-casting tooling. Wear, 2004, 256, 38-43.
8 Olive, S. Long-life die design. Diecasting World, 2005, 14(1), 15.

9 Bendyk, J. C., Maracz, O. J., and Wallace, J. F. Thermal fatigue behaviour of die materials for aluminium die casting. In Proceedings of the Sixth SDCE International Die Casting Congress, Cleveland, Ohio, USA, 16-19 November 1970, paper 111, pp. 1-20.

10 Persson, A. Strain-based approach to crack growth and thermal fatigue life of hot work tool steels. Scand. J. Metall., 2004, 33(1), 53-64.

11 Persson, A., Hogmark, S., and Bergstrom, J. Temperature profiles and conditions for thermal fatigue cracking in brass die casting dies. J. Mater. Process. Technol., 2004, 152, 228-236.

12 Bounds, S. An Experimental and numerical investigation into thermal behaviour of the pressure die casting process. Trans. ASME, J. Mfg Sci. Engng, 2000, 122, 90-99.

13 Anon. Don't let the cracks show. Cast Metal Die-casting Times, December 2003-January 2004, 6(1), 13.

14 Chen, Z. W. Skin solidification during high pressure die casting of Al-11Si-2Cu-1Fe alloy. Mater. Sci. Engng A, 2003, 348, 145-153.

15 Ghomashchi, M. R. High pressure die casting: effect of fluid flow on the microstructure of LM24 die casting alloy. J. Mater. Process. Technol., 1995, 52, 193-206.

16 Oberg, E., Franklin, D. J., Holbrook, L., and Henry, H. P. Machinery's handbook, 25th Edition, 1996 (Industrial Press, New York). 